\title{
ПРОФЕССИОНАЛЬНО ЗНАЧИМЫЕ КАЧЕСТВА УЧАЩЕГОСЯ-МУЗЫКАНТА И ИХ ФОРМИРОВАНИЕ В ПРОЦЕССЕ СОЗДАНИЯ ТРАНСКРИПЦИИ
}

\section{PROFESSIONALLY IMPORTANT QUALITIES STUDENT-MUSICIAN AND THEIR FORMATION IN THE PROCESS OF TRANSCRIPTION}

\section{Beketova}

Summary: Currently, there is an extraordinary rise in the musical and performing arts and the demand for transcription as a type of creative activity of a musician, which is associated with the conditions of competition between academic musicians and representatives of mass culture. But few musicians have the skills to create an artistically convincing, interesting transcription for the listener, since due attention is not paid to this type of activity within the framework of the educational process. In addition to the field for creative experiments, transcription also performs a pedagogical function - it can be used as an effective means of developing a musician's personality, contributing to the formation of a complex of professionally significant qualities of a musician-performer required not only for this creative activity, but also for his self-realization in the profession as a whole.

Keywords: professionally important qualities, musical transcription, personal development of a musician, creating a musical transcription.
B современном высокотехнологичном мире все сферы претерпевают значительные изменения, в том числе и музыкально-исполнительское искусство. В условиях конкуренции с представителями массовой культуры, многие музыканты-исполнители различных академических специальностей в целях профессиональной самореализации, а также для привлечения широкой слушательской аудитории, постоянно находятся в поиске интересных сочинений для составления концертных программ, создают новые нетипичные составы ансамблей, соединяя самые разнообразные инструменты. Творческие эксперименты часто приводят музыкантов к созданию «своего» репертуара, т.е. написанного специально для этого состава исполнителей, отражающего его особенности. Поскольку подобных сочинений немного, востребованными оказываются транскрипции.

Транскрипция в данной статье используется в значении вида творческой деятельности музыканта-исполнителя, предполагающей создание нового сочинения на основе уже существующего музыкального произведения [1]. Как собирательное понятие транскрипция вклю-
Бекетова Марина Александровна

Преподаватель, Московский государственный институт музыки имени А.Г. Шнитке, г. Москва marina_zhukova1988@mail.ru

Аннотация: В настоящее время в музыкально-исполнительском искусстве наблюдается необычайный подъем и востребованность транскрипции как вида творческой деятельности музыканта, что связано с условиями конкурентности академических музыкантов с представителями массовой культуры. Но навыками создания художественно убедительной, интересной слушателю транскрипции обладают немногие музыканты, поскольку в рамках учебного процесса этому виду деятельности не уделяется должного внимания. Кроме поля для творческих экспериментов, транскрипция выполняет и педагогическую функцию - может быть использована в качестве эффективного средства развития личности музыканта, способствовать формированию комплекса профессионально значимых качеств музыканта-исполнителя, требуемого не только для данного творческого вида деятельности, но и в целом для его самореализации в профессии.

Ключевые слова: профессионально значимые качества музыканта, профессионально важные качества музыканта, музыкальная транскрипция, создание транскрипции музыкантом.

чает в себя различные виды преобразования авторского музыкального текста: переложения, обработки, транскрипции, аранжировки.

Создание транскрипции - довольно сложный процесс, требующий специальных знаний, умений и навыков. Транскрипция отражает художественный вкус, творческий потенциал, уровень мышления, исполнительское мастерство ее создателя. И в то же время, сам процесс создания транскрипции позволяет совершенствовать указанные психические процессы, развивать способности музыканта и формировать комплекс профессионально значимых качеств, требуемый не только для данного творческого вида деятельности, но и в целом для его самореализации в профессии. Музыкант, способный быстро и с высоким художественным результатом варьировать музыкальный текст, понимающий природу своего инструмента, знающий особенности стилей и закономерности музыкального языка, умеющий «на ходу» преобразовывать фактуру, при этом, не теряя художественный компонент, а раскрывая музыкальный образ возможностями своего инструмента, в настоящее время 
крайне востребован.

Вместе с тем многие музыканты не учатся целенаправленно создавать транскрипции в процессе обучения, что значительно ограничивает их возможности в профессиональной деятельности. По окончании учебного заведения выпускники довольно часто оказываются неподготовленными к условиям труда именно с точки зрения несформированности в нужной степени профессиональных качеств. Они владеют обширными знаниями, эрудированы, мотивированны, владеют на высоком уровне исполнительским мастерством, но многие не обладают личностными и профессиональными качествами, необходимыми для самореализации в современных реалиях, и приобретенный в ходе обучения багаж знаний и умений не находит применения в практике. Это приводит к психологическому стрессу, потере интереса к выбранной профессии.

В научных исследованиях по психологии труда профессионально значимые качества (сокращенно ПЗК) рассматриваются как индивидуальные свойства субъекта деятельности, необходимые для успешного выполнения той или иной профессиональной деятельности. ПЗК являются составной частью профессионального мастерства и в совокупности с направленностью, знаниями, умениями, опытом обеспечивают профессиональную пригодность и компетентность специалиста, способствуют его самореализации. Данные качества формируются на пересечении индивидуально-личностных и профессиональных качеств, и, с одной стороны являются необходимой предпосылкой к деятельности (должны быть сформированы на определенном уровне в ходе обучения специалиста), с другой стороны, они совершенствуются в процессе самой профессиональной деятельности, способствуя появлению новых качеств и образуя все более сложные системы.

Понятие профессионально значимых качеств стало активно разрабатываться с середины XX века в исследованиях ученых-психологов В.Д. Шадрикова, А.К. Марковой, А.В. Карпова, Е.А. Климова и др. Несмотря на различие в формулировках понятия, определении структуры ПЗК, во всех трудах подчеркивается, что успешность овладения профессией, продуктивность и эффективность труда во многом зависят от степени сформированности комплекса личностных и профессиональных качеств специалиста.

Относительно музыкального исполнительства и педагогики проблема развития личности музыканта, формирования профессионально значимых качеств разрабатывалась учеными-психологами и исследователями в области музыкально-исполнительского искусства. Одним из первых фундаментальных трудов является исследование Б.М. Теплова, подробно раскрывающее понятие музыкальных способностей и особенности их развития. Продолжение идей ученого получило в трудах Д.К. Кирнарской, М.С. Старчеус, В.И. Петрушина и др.

Понятие профессионально значимых качеств относительно людей творческих профессий, в том числе музыкантов, раскрывается в труде «Дифференциальная психология» ученого-психолога Е.П. Ильина. Он выявляет сущность и соотношение понятий «способности» и «качества»: «Важное отличие понятия «качество» от способностей состоит в том, что первое может характеризовать не только функциональные возможности человека, но и его как личность. Поэтому наряду с двигательными качествами, качествами ума и т.п. выделяют нравственные, волевые, причем первые не связаны с врожденными особенностями человека, а приобретаются в процессе его социализации и воспитания. <...> в процессе овладения профессиональным мастерством каждая способность, реализуясь в конкретных действиях, получает свою огранку, превращаясь в профессионально важное качество» [2, С. 42].

Согласно концепции ученого, качества являются проявлением какой-либо функциональной возможности человека, базирующееся на той или иной способности. Профессионально значимые качества ученый относит к функциональным качествам.

Опираясь на положения Е.П. Ильина, Ю.А. Цагарелли сужает проблему профессиональных качеств от обобщенных, относящихся ко всем направлениям музыкальной деятельности (исполнитель, композитор, музыковед), к исполнительской. Наряду с направленностью, знаниями и умениями ученый относит качества к основным слагаемым профессионального мастерства музыканта-исполнителя. Под качествами ученый понимает «фенотипическую характеристику человека, отражающую наличный уровень проявления того или иного психического процесса (памяти, мышления и т.п.) и характеристик движений (силы, быстроты, точности и т.д.)» [4, c. 11].

Исследователь разделяет структуру профессионально значимых качеств на две подструктуры:

- Общемузыкальные (необходимые всем музыкантам, независимо от сферы деятельности): сенсорно-перцептивные, эмоциональные, мнемические, интеллектуальные и имажинитивные;

- Непосредственно-исполнительские: психомоторные (исполнительская техника), артистизм, надежность в концертном выступлении, аттенционные, коммуникативные, волевые) качества.

Отдельно ученый выделяет нравственные качества, которые определяют «направленность репертуарной политики, общий облик музыканта» [4, с. 11]. 
Также целостно, не разделяя качества по узким специализированным направлениям, ученый Г.М. Цыпин обобщает все направления деятельности музыкантовисполнителей и определяет следующие профессионально значимые качества, являющиеся залогом самореализации и востребованности молодого специалиста в современном мире [5, с. 197-198]:

- готовность к овладению новыми, ранее незнакомыми видами деятельности; мобильность, способность варьировать и обогащать имеющийся комплекс умений и навыков; при необходимости совмещать профессии, переключаясь по мере надобности от одной профессии к другой;

- установка на саморазвитие;

- креативность мышления, выражающаяся в способности генерировать интересные, нестандартные идеи;

- коммуникабельность как свойство характера человека;

- компетентность в области современных компьютерных технологий.

Обобщая достижения Е.П. Ильина и Ю.А. Цагарелли, Р.Ф. Сулейманов концентрируется только на музыкально-инструментальной деятельности. Ученый справедливо подчеркивает, что структуры профессиональных качеств, например, солирующего исполнителя, артиста оркестра и концертмейстера значительно отличаются. Следовательно, каждый вид музыкально-исполнительской деятельности имеет свой индивидуальный набор профессиональных качеств, влияющий на успешность освоения профессии и эффективность дальнейшей деятельности, и должен рассматриваться отдельно.

Р.Ф. Сулейманов выделяет два важнейших умения, которые определяют успешность профессиональной деятельности музыканта-инструменталиста - чтение с листа музыкальных произведений и игра по слуху. Относительно этих умений ученый подробно раскрывает иерархическую структуру профессионально важных качеств, рассматривая процесс их развития на трех уровнях: музыкальная школа, среднее профессиональное и высшее образование.

В данной статье процесс формирования комплекса профессионально значимых качеств рассматривается в аспекте работы учащегося-музыканта над транскрипциями музыкальных произведений.

Использование транскрипции в качестве средства обучения позволяет интенсифицировать развитие личности музыканта и сформировать комплекс профессионально значимых качеств. Аккумулируя и анализируя опыт ведущих ученых и основываясь на концепции Г.М. Цыпина в области музыкальной педагогики, сформулированы качества, формируемые в процессе транскрип- торской деятельности:

1. Готовность, способность и потребность в постоянном обогащении и варьировании имеющегося комплекса знаний, умений, навыков, в том числе и овладении новыми видами деятельности.

Регулярное создание учащимся-музыкантом транскрипции музыкального произведения (под руководством преподавателя или полностью самостоятельно) предполагает изучение учащимся-музыкантом в большом объеме произведений разных эпох, стилей, направлений, что стимулирует постоянное обогащение знаний в области истории и теории музыки, музыкального исполнительства, а также изучение технических и выразительных возможностей различных инструментов.

2. Креативность, гибкость мышления, активность воображения, способность генерировать интересные, нестандартные идеи.

Создание транскрипции - это всегда творческое преобразование и варьирование различными способами музыкального текста, которое безусловно активизирует воображение, дивергентное мышление, позволяет раскрывать творческий потенциал обучающегося.

3. Техническая оснащенность учащегося-музыканта.

Создание транскрипции способствует интенсивному развитию и совершенствованию технических навыков музыканта, поскольку требует тщательной проработки музыкального материала (тонкости преобразования средств выразительности (артикуляции, фразировки и др.). Довольно часто фактурное изложение невозможно пересочинить для удобного исполнения по причинам нарушения стилистики, в связи с чем музыкант-исполнитель должен найти нетипичные способы технического воплощения, не изменяя текст оригинала (нестандартная аппликатура, особенности применения приемов игры).

4. Ряд индивидуально-личностных качеств:

- волевые качества (целеустремленность, настойчивость, усидчивость, терпеливость, инициативность, решительность);

- коммуникабельность (если говорить о совместной работе в ансамбле, например);

- самостоятельность;

- рефлексивность;

- организованность;

- внимательность.

Создание транскрипции в некотором смысле имеет схожие черты с сочинением музыки, и чтобы преобразования были органичными, естественными и не искажали 
музыкальный образ необходимо думать, как композитор. Тщательная, кропотливая работа над фактурой требует волевых качеств, внимательности. При совместной работе (например, над транскрипцией для ансамбля) требуется согласование своих творческих намерений с другими исполнителями, развивает коммуникативные качества.

5. Компетентность в области современных информационно-коммуникационных технологий.

Поиск различных нотных изданий, уртекста, возмож- ных существующих вариантов транскрипций, аудио- или видеозаписей ведущих музыкантов-исполнителей, нотный набор собственной транскрипции - всё это интенсифицирует освоение ИКТ, в том числе специального программного обеспечения для музыкантов.

Безусловно, указанные профессионально значимые качества в определенной степени формируются в целом в ходе обучения учащегося-музыканта всеми дисциплинами учебного плана, но в работе с транскрипциями они развиваются более интенсивно, системно, целенаправленно.

\section{ЛИТЕРАТУРА}

1. Бородин Б.Б. История фортепианной транскрипции: эволюция направлений, стилей и методов в контексте художественной культуры: монография / Б.Б. Бородин. - М.: 000 «Дека-ВС», 2011. -508 с.

2. Ильин Е.П. Дифференциальная психология профессиональной деятельности / Е.П. Ильин. - СПб.: Питер, 2008. - 432 с.

3. Сулейманов Р.Ф. Психология профессионального мастерства музыканта-инструменталиста / Р.Ф. Сулейманов. - Казань: Изд-во «Познание» Института экономики, управления и права, 2010. - 328 с.

4. ЦЦагарелли, Ю.А. Психология музыкально-исполнительской деятельности: учебное пособие / Ю. А. Цагарелли. - СПб.: Композитор, 2008. - 367 с.

5. Ц Цыпин Г.М. Психология творческой деятельности. Музыка и другие искусства : учеб. Пособие для академического бакалавриата / Г.М. Цыпин. - Москва: Юрайт, 2018. - 203 с.

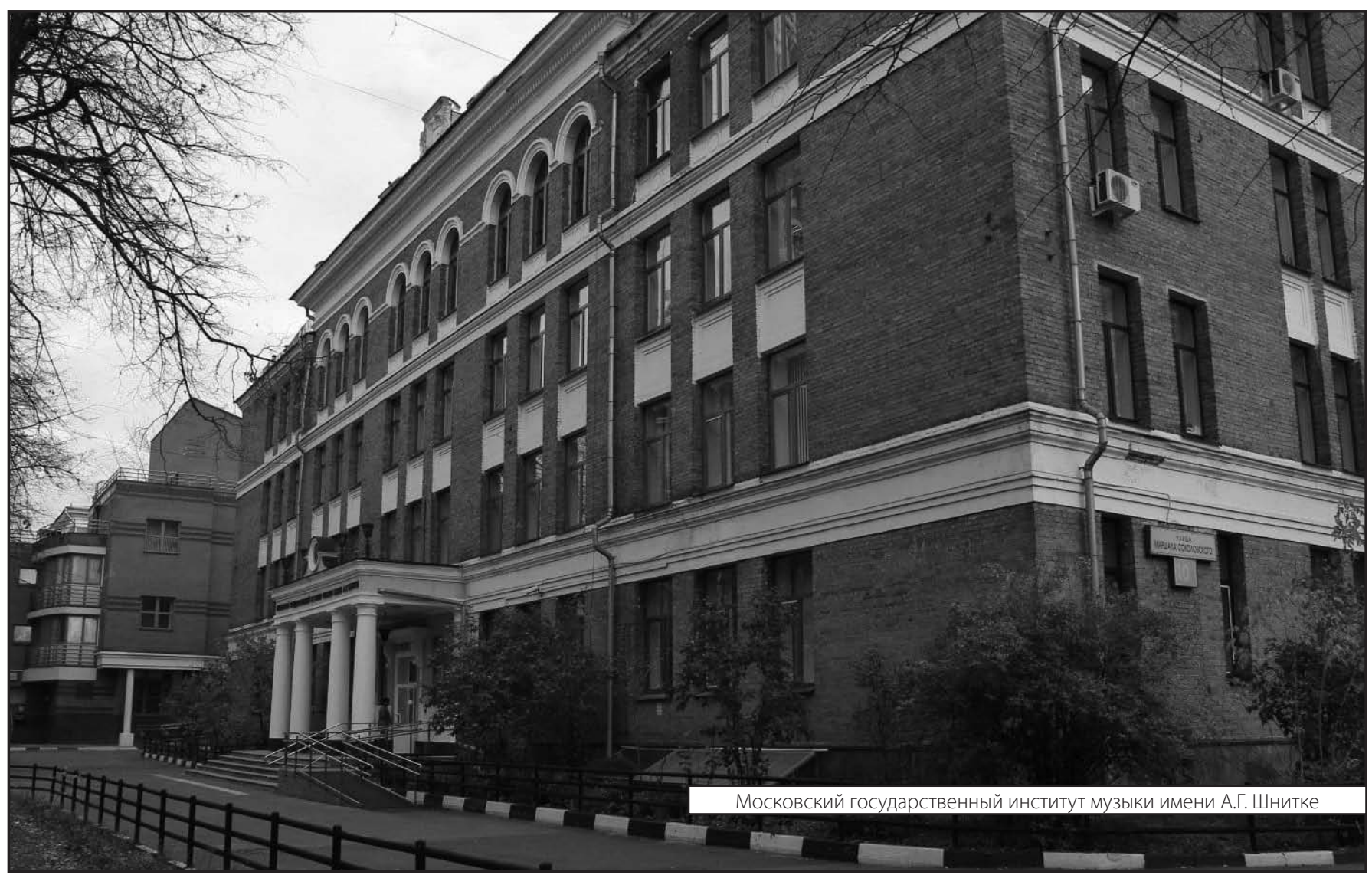

